\title{
Status Report on Modifications to MELCOR for modeling of Accident Tolerant Fuel (ATF)
}

Paul W. Humrickhouse Brad J. Merrill

\author{
August 2017
}

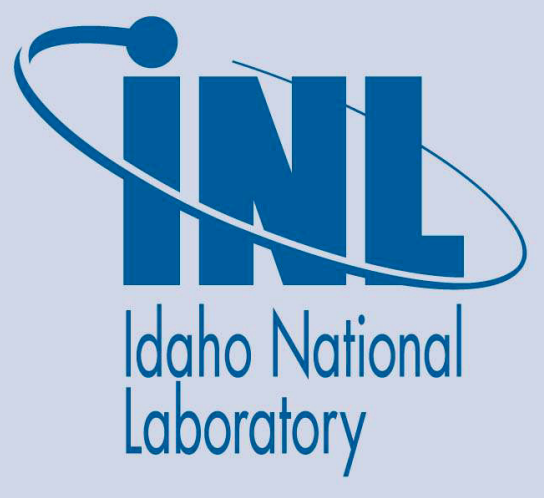

The INL is a U.S. Department of Energy National Laboratory operated by Battelle Energy Alliance 


\section{DISCLAIMER}

This information was prepared as an account of work sponsored by an agency of the U.S. Government. Neither the U.S. Government nor any agency thereof, nor any of their employees, makes any warranty, expressed or implied, or assumes any legal liability or responsibility for the accuracy, completeness, or usefulness, of any information, apparatus, product, or process disclosed, or represents that its use would not infringe privately owned rights. References herein to any specific commercial product, process, or service by trade name, trade mark, manufacturer, or otherwise, does not necessarily constitute or imply its endorsement, recommendation, or favoring by the U.S. Government or any agency thereof. The views and opinions of authors expressed herein do not necessarily state or reflect those of the U.S. Government or any agency thereof. 


\section{Status Report on Modifications to MELCOR for modeling of Accident Tolerant Fuel (ATF)}

Paul W. Humrickhouse

Brad J. Merrill

August 2017

Idaho National Laboratory

Idaho Falls, Idaho 83415

http://www.inl.gov

Prepared for the

U.S. Department of Energy

Office of Nuclear Energy

Under DOE Idaho Operations Office

Contract DE-AC07-05ID14517 


\section{Introduction}

Accident Tolerant Fuels and cladding materials are being investigated as a way to provide a greater resistance to fuel degradation, oxidation, and melting under severe accident conditions. Scoping simulations performed using a severe accident code can be applied to investigate the influence and potential safety advantages of these advanced materials on beyond design basis accident progression and to identify any existing code limitations. To this end, customized versions of the MELCOR code, under development at Sandia National Laboratories in New Mexico (SNL/NM), have been developed at INL which replace Zircaloy with $\mathrm{SiC}$ or FeCrAl in the MELCOR reactor core oxidation and material properties routines. Prior versions hard-wired the new material properties, as Zirconium had been. In FY17, MELCOR was further generalized to allow for all the relevant properties to be specified by code users in the input file; the result is a User Defined Generalized Coating (UDGC) version of MELCOR that allows users to model any arbitrary metal clad or clad coating via the use of these user inputs. These code changes and the modified input file format are described in this report. The new code is now being used at the University of Wisconsin and INL to investigate the effects of FeCrAl cladding on severe accident progression, and in particular any possible synergistic effect of both ATF cladding and extended Auxiliary Feed Water (AFW) operation using a model of the Surry Pressurized Water Reactor (PWR).

\section{Description of MELCOR}

The MELCOR code is the primary code used by the Nuclear Regulatory Commission (NRC) to model and analyze the progression of severe accidents [1]. MELCOR is being developed and maintained for the NRC by SNL/NM. MELCOR is a systems level severe accident code which includes the major phenomena of the system thermal hydraulics, fuel heat-up, cladding oxidation, radionuclide release and transport, fuel melting and relocation, etc.

MELCOR is presently designed for current light water reactor (LWR) core material configurations. It contains models for typical LWR components such as fuel, cladding, spacer grids, support plates and channel boxes. These components have a fixed list of allowable materials that comprise them; for example, cladding may be composed of only $\mathrm{Zircaloy}, \mathrm{ZrO}_{2}$, and/or Inconel. The properties of these materials are built in to the code. The user can change the defined properties of one of these materials, such as Zircaloy, through user input. Internally, however, the code assigns material composition according to core component. As a result, a material property change to one of the core components, e.g. the cladding, will also change the material composition and properties of other core structures, e.g. channel boxes. This assumption can only be changed by modifying the code to consider additional materials for any given core component, which has been a focus of this activity.

\section{MELCOR modifications for User Defined Generalized Cladding}

Initial modifications to MELCOR to model alternate claddings (in this case $\mathrm{SiC}$ ) were completed at Idaho National Laboratory (INL) in FY 2012 [2]. INL also focused on applying this modified MELCOR code to the Three Mile Island Unit 2 (TMI-2) loss-of-coolant accident (LOCA). The TMI-2 accident was caused by a small-break LOCA in a two-loop Babcock and Wilcox (B\&W) PWR. The MELCOR input model used for this accident analysis is that developed by SNL-NM and Innovative Technology Solutions Corporation, Albuquerque, NM [3]. These early modifications directly substituted SiC for Zircaloy in all of MELCOR's core components. A similarly customized version was developed for 
FeCrAl claddings and applied to the same accident analysis [4]. This approach had the shortcoming that all Zircaloy structure properties (not just the fuel clad or clad coating) would be overwritten. Following those initial studies, subsequent modifications were made that allowed an alternate cladding (or clad coating) and it's oxide to be defined as additional materials in both the core physics and materials properties data packages. The present work extends those modifications to allow for the additional properties to be specified via user input.

To accommodate the UDGC model and user input, MELCOR was modified so as to read additional words from the relevant cards in the core (COR) package that specify the mass of UDGC and UDGCoxide in each cell following those for zirconium and zirconium oxide; specific input requirements and examples are given in Section 5 below. Either the zirconium or UDGC masses may be zero, in which case the clad is composed entirely of the metal specified; if both masses are non-zero, the clad is assumed to be duplex with UDGC on the outside of zirconium. If UDGC properties are not specified by the user, Zircaloy properties are used by default.

While making the Fortran coding changes for the UDGC version of the MELCOR code, it was discovered that the core convective heat transfer subroutine followed the convection heat transfer correlations specified in Section 2.3 of the MELCOR User Reference Manual for vapor convection, but not for pool convection. Instead, for the pool convection a constant value was set for the convective heat transfer coefficient of $1,000 \mathrm{~W} / \mathrm{m}^{2}-\mathrm{K}$. It is not clear why this approach was taken for the pool; it is possible that this has been revised in newer versions of the MELCOR source code. However to correct this issue the same convective correlations used for the vapor were also included for the pool in this UDGC version of the modified MELCOR code instead of the fixed value of $1,000 \mathrm{~W} / \mathrm{m}^{2}-\mathrm{K}$.

Oxidation of the UDGC makes use of the existing MELCOR oxidation routines, i.e. it is assumed to undergo parabolic oxidation in both air and water (e.g. metals). The adopted UDGC cladding and coating failure temperature is that of the melting temperature of its oxide. If UDGC is the only cladding material in a core zone, then this criterion becomes that for rod failure. If Zircaloy is present in the same core volume, then the rod failure and candling criteria revert back to those for Zircaloy after reaching the UDGC failure criterion. Upon coating failure, the UDGC in that volume enters the debris field in the same volume, where it continues to undergo further oxidation by steam.

In order to model a UDGC other than Zircaloy in this version of MELCOR, the following material properties and behaviors must be given:

- Properties of the base material (e.g. FeCrAl) and its oxide, as a function of temperature:

- Melting temperature $\left(\mathrm{T}_{\text {melt }}[\mathrm{K}]\right)$ of the base material, oxide and any eutectics that may form

○ Thermal conductivity $(\mathrm{k}[\mathrm{W} / \mathrm{m}-\mathrm{K}])$

$\circ$ Specific heat $\left(\mathrm{c}_{\mathrm{p}}[\mathrm{J} / \mathrm{kg}-\mathrm{K}]\right)$

$\circ$ Density $\left(\rho\left[\mathrm{kg} / \mathrm{m}^{3}\right]\right)$

$\circ$ Emissivity $\left(\varepsilon\left[\mathrm{W} / \mathrm{m}^{2}-\mathrm{K}^{4}\right]\right)$

- Oxidation reactions, including oxidation rate, heat- of-reaction, reaction products, etc.

- Coefficients for Arrhenius relationship for parabolic oxidation rate behavior

Values used in the FeCrAl analyses described below are given in Section 4, and a modified portion of the MELCOR manual describing the new input requirements are given along with examples in Section 5. 


\section{Properties of FeCrAl}

The thermophysical properties of FeCrAl modeled as a UDGC in the analyses below are given in Tables 1-2. The UDGC-oxide is assumed to have the properties of stainless steel oxide as listed in the MELCOR theory manual [1]; as FeCrAl is an alloy, there are different approaches to modeling its oxide, which are discussed in more detail below.

Table 1. Properties of FeCrAl [6-8].

\begin{tabular}{cccc}
\hline \multicolumn{2}{c}{ Thermal Conductivity } & \multicolumn{2}{c}{ Specific Heat } \\
Temp (K) & W/m-K & Temp (K) & J/kg-K \\
\hline 273 & 9.95 & 273 & 447.35 \\
300 & 10.54 & 300 & 464.80 \\
400 & 12.57 & 400 & 522.55 \\
500 & 14.37 & 500 & 570.33 \\
600 & 15.98 & 600 & 609.25 \\
700 & 17.46 & 700 & 640.41 \\
800 & 18.86 & 773 & 658.89 \\
900 & 20.24 & 823 & 696.33 \\
1000 & 21.63 & 873 & 750.00 \\
1200 & 24.69 & 923 & 714.01 \\
1400 & 28.46 & 973 & 694.81 \\
1600 & 33.34 & 1000 & 698.35 \\
1700 & 36.34 & 1200 & 718.41 \\
1773 & 38.79 & 1400 & 733.91 \\
2000 & 46.42 & 1600 & 753.70 \\
\hline 5000 & 46.42 & 1700 & 767.96 \\
& & 1773 & 781.08 \\
\hline
\end{tabular}

Table 2. Adopted FeCrAl properties for MELCOR modeling [5-9].

\begin{tabular}{|l|r|r|}
\hline Adopted Material Properties & FeCrAl & FeCrAl Oxide \\
\hline Meltinq Point $(\mathrm{K})$ & 1773 & 1901 \\
\hline Heat of Fusion $(\mathrm{J} / \mathrm{kg})$ & 275000 & 687463 \\
\hline Density $\left(\mathrm{kg} / \mathrm{m}^{3}\right)$ & 7098.5 & 5180 \\
\hline Thermal Conductivity $(\mathrm{W} / \mathrm{m} \mathrm{K})$ & & 4.0 \\
\hline Specific Heat $(\mathrm{J} / \mathrm{kg} \mathrm{K})$ & & 900.0 \\
\hline Heat of Reaction, $\mathrm{H}_{2} \mathrm{O} @ 298 \mathrm{~K}\left(\mathrm{~kJ} / \mathrm{kg}_{\text {fecral }}\right)$ & $1114^{\dagger}$ & -- \\
\hline
\end{tabular}

${ }^{\dagger}$ Composition weighted average of $\mathrm{Fe}, \mathrm{Cr}$, and $\mathrm{Al}$ oxides.

Oxidation of $\mathrm{FeCrAl}$ in air or steam exhibits a parabolic reaction rate, i.e. the square of the thickness of the oxide layer formed is proportional to exposure time: 


$$
x^{2}=k_{p} t .
$$

The parabolic rate constant $k_{p}$ is given by:

$$
k_{p}=k_{p}^{o} \exp \left(-E_{a} / R T\right) .
$$

Recently Pint [10] produced parabolic oxidation data for Kanthal's Advanced Powder Metallurgy Tube $\left(\mathrm{APMT}^{\circledR}\right.$ ) alloy for both air and steam. This FeCrAl alloy contains 69\% Fe, $21.6 \% \mathrm{Cr}, 4.9 \% \mathrm{Al}$, plus various other minor constituents. A copy of Fig. 5 of Ref. 10 has been reproduced here in Fig. 1. Pint does not present values for the pre-exponential factor and activation energy for APMT reactions in air and steam; for our application, these were obtained by digitizing Pint's data and the lines drawn in Fig. 1 used to determine a $k_{p, O 2}^{o}$ of $6.6998\left(\mathrm{~kg}^{2}-\mathrm{FeCrAl} / \mathrm{m}^{4}-\mathrm{s}\right)$ and an $E_{a, O 2}$ of $294(\mathrm{~kJ} / \mathrm{mol}-\mathrm{K})$ for air and a $k_{p, H 2 O}^{o}$ of $5.213 \times 10^{-1}\left(\mathrm{~kg}^{2}-\mathrm{FeCrAl} / \mathrm{m}^{4}-\mathrm{s}\right)$ and an $E_{a, H 2 O}$ of $260(\mathrm{~kJ} / \mathrm{mol}-\mathrm{K})$ for steam, which we have adopted for this MELCOR modification.

Measured heat-of-reaction for oxidation of $\mathrm{FeCrAl}$ in air or steam could not be found in the literature. In estimating these quantities, the approach used by the SNL/NM MELCOR developers for stainless steel was used in this modification. This approach is to mole-weight the heat-of-reaction of the constituent elements $(\mathrm{Fe}, \mathrm{Cr}$ and $\mathrm{Al})$ to determine a heat-of-reaction for the alloy. Using this method results in a heat-of-reaction of $\sim 7.507 \times 10^{6}(\mathrm{~J} / \mathrm{kg}-\mathrm{FeCrAl})$ and $\sim 1.114 \times 10^{6}(\mathrm{~J} / \mathrm{kg}-\mathrm{FeCrAl})$ for air and steam at 298 $\mathrm{K}$, respectively. However, Ref. 11 demonstrates that the oxide layer that forms on $\mathrm{FeCrAl}$ is primarily $\mathrm{Al}_{2} \mathrm{O}_{3}(60 \%$ to $90 \% \mathrm{Al})$ and not an oxide with the same composition of oxides $\left(\mathrm{FeO}, \mathrm{Cr}_{2} \mathrm{O}_{3}\right.$ and $\left.\mathrm{Al}_{2} \mathrm{O}_{3}\right)$ as the base metal $(70 \% \mathrm{Fe}, 23.5 \% \mathrm{Cr}$ and $5.8 \% \mathrm{Al})$. If this is the case, then the heat-of-reaction would be more like that of aluminum reacting with air and steam, which are $\sim 3.016 \times 10^{7}(\mathrm{~J} / \mathrm{kg}-\mathrm{FeCrAl})$ and $\sim 1.518$ $\times 10^{7}(\mathrm{~J} / \mathrm{kg}-\mathrm{FeCrAl})$ at $298 \mathrm{~K}$, respectively. These numbers are $\sim 4$ and $\sim 12$ times higher than those from the weighted approach. However, if the scale is really mostly alumina, then perhaps its melting temperature is closer to that of alumina $(2323 \mathrm{~K})$ instead of the adopted value of $1901 \mathrm{~K}$.

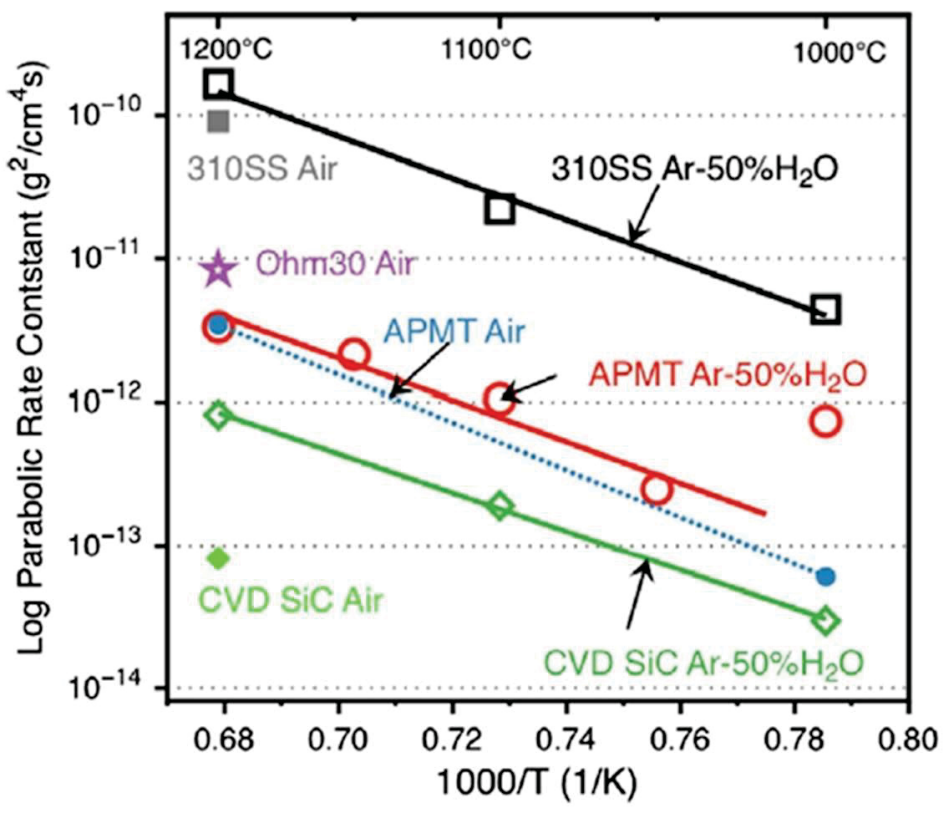

Figure 1. FeCrAl oxidation data for air and steam (from [10]). 


\section{MELCOR User Input Changes Required to Execute the User Defined Generalized Coating Material Option}

Very few changes to MELCOR's user input are required for a user to apply a UDGC material to MELCOR's cladding material. The user must specify the mass of UDGC material through the "Cladding Component Masses" input card and its oxidation parameters through sensitivity coefficient "1001 Zircaloy Oxidation Rate Constant Coefficients" of MELCOR's core physics package user input and specify the UDGC material's thermal properties through the MELCOR's material properties package (note: internally, the new material called UDGC and UDGC-OXIDE have been added to this MELCOR's materials package). The default for these parameters are those already defined as Zircaloy default properties within the MELCOR code. The required user input changes are in blue text to override these default parameters are listed below.

CORijjKCL - Cladding Component Masses

$1 \leq \mathrm{i} \leq \mathrm{NRAD}$, $\mathrm{i}$ is the radial ring number

$1 \leq \mathrm{jj} \leq \mathrm{NAXL}$, $\mathrm{jj}$ is the axial level number

Optional

This record specifies the initial masses of the cladding component in cell ijj. This record is not generally required, but component masses for at least one component must be entered if the new-format option is exercised for this cell. Three floating point fields are allowed on this record. If any fields on this record are missing or are set to -1.1 (or if the record is not present), the corresponding values from reference cell IREFN are used if IREFN is defined; otherwise, the values are set to zero.

(1) XMCLZR - Mass of Zircaloy in the cell cladding component. (type $=$ real, default $=-1.1$, units $=\mathrm{kg}$ )

(2) XMCLIN - Mass of Inconel associated with the cell cladding component (e.g., PWR grid spacers). (type $=$ real, default $=-1.1$, units $=\mathrm{kg}$ )

(3) XMCLZX - Mass of ZrO2 in the cell cladding component. (type $=$ real, default $=-1.1$, units $=\mathrm{kg}$ )

For the User Defined Generalized Coating (UDGC) version

(4) XMCLGC - Mass of UDGC material in the cell cladding component.

(type $=$ real, default $=-1.1$, units $=\mathrm{kg}$ )

(5) XMCLGX - Mass of UDGC material oxide in the cell cladding component. $($ type $=$ real, default $=-1.1$, units $=\mathrm{kg})$

This record specifies the initial masses of the cladding component in cell ijj. This record is not generally required, but component masses for at least one component must be entered if the new-format option is exercised for this cell. Five floating point fields are allowed on this record. If any fields on this record are missing or are set to -1.1 (or if the record is not present), the corresponding values from reference cell IREFN are used if IREFN is defined; otherwise, the values are set to zero. If the user wishes the UDGC 
material to constitute the entire cladding, then the only non-zero mass that the user should enter is that for the UDGC material.

Oxidation parameters for the UDGC material must also be defined. The logic of the modified code will oxidize the UDGC material first by using the user entered oxidation constants for this material by way of the core physics package sensitivity constant 1001 (input in blue text below is required).

\section{1 - Zircaloy Oxidation Rate Constant Coefficients}

These coefficients are used to calculate the rate constant for oxidation of Zircaloy by parabolic kinetics. The rate constant $\mathrm{K}\left(\mathrm{kg}^{2} / \mathrm{m}^{4}\right.$-s) as a function of temperature $\mathrm{T}(\mathrm{K})$, where $\mathrm{I}=1$ for oxidation by $\mathrm{H}_{2} \mathrm{O}$ and $\mathrm{I}=2$ for oxidation by $\mathrm{O}_{2}$.

$(1, \mathrm{I})$ - low temperature range constant coefficient (default $=29.6$ for $\mathrm{I}=1,50.4$ for $\mathrm{I}=2$; units $=\mathrm{kg}^{2}(\mathrm{Zr}) / \mathrm{m}^{4}-\mathrm{s}$, equiv $=$ none $)$

$(2, \mathrm{I})$ - low temperature range exponential constant (default $=16820.0$ for $\mathrm{I}=1,14630.0$ for $\mathrm{I}=2$; units $=\mathrm{K}$, equiv $=$ none $)$

$(3, I)$ - high temperature range constant coefficient (default $=87.9$ for $\mathrm{I}=1,0.0$ for $\mathrm{I}=2$; units $=\mathrm{kg}^{2}(\mathrm{Zr}) / \mathrm{m}^{4}-\mathrm{s}$, equiv = none)

$(4, \mathrm{I})$ - high temperature range exponential constant (default $=16610.0$ for $\mathrm{I}=1,0.0$ for $\mathrm{I}=2$; units $=\mathrm{K}$, equiv $=$ none $)$

$(5, I)$ - upper temperature boundary for low temperature range (default $=1853.0$ for $\mathrm{I}=1,10000.0$ for $\mathrm{I}=2$; units $=\mathrm{K}$, equiv $=$ none $)$

$(6, I)$ - lower temperature boundary for high temperature range (default $=1873.0$ for $\mathrm{I}=1,10000.0$ for $\mathrm{I}=2$; units $=\mathrm{K}$, equiv $=$ none $)$

For the UDGC version of MELCOR the following input is required:

$(7, I)$ - pre-exponential rate constant coefficient (default $=0.0$ for $\mathrm{I}=1$, zero for $\mathrm{I}=2$; units $=\mathrm{kg}^{2}(\mathrm{UDGC}) / \mathrm{m}^{4}-\mathrm{s}$, equiv $=$ none $)$

$(8, I)$ - exponential constant (default $=0.0$ for $\mathrm{I}=1,0.0$ for $\mathrm{I}=2$; units $=\mathrm{K}$, equiv $=$ none $)$

$(9, \mathrm{I})$ - heat of oxidation reaction (J/kg-UDGC metal oxidized) (default $=0.0$ for $\mathrm{I}=1,0.0$ for $\mathrm{I}=2$; units $=\mathrm{kg}^{2}(\mathrm{UDGC}) / \mathrm{m}^{4}-\mathrm{s}$ )

$(10, I)$ - mass of UDGC metal oxide produced/mass UDGC metal oxidized, I=1 and mass CO produced/mass UDGC metal oxidized, I=2 (default $=0.0$ for $\mathrm{I}=1,0.0$ for $\mathrm{I}=2$; units $=$ none $)$

$(11, \mathrm{I})$ - mass $\mathrm{H}_{2} \mathrm{O}$ consumed/mass UDGC metal oxidized, I=1, and mass $\mathrm{O}_{2}$ consumed/mass UDGC metal oxidized, $\mathrm{I}=2$ (default $=0.0$ for $\mathrm{I}=1,0.0$ for $\mathrm{I}=2$; units = none)

(note: The default for the new constants is zero. If $1001(7, \mathrm{l})$ is zero, then the modified version of MELCOR reverts to 1001(1-6,I) for oxidation constants of the UDGC material)

Examples of user input required to define a cladding coating material for the INL modified UDGC version of MELCOR 1.8.6.

Core physics package input

$\begin{array}{lrrrrr}* & \text { XMCLZR } & \text { XMCLIN } & \text { XMCLZX } & \text { XMCLGC } & \text { XMCLGX } \\ \text { COR101KCL } & 79.301 & 0.0 & 0.0 & 173.205 & 0.0\end{array}$




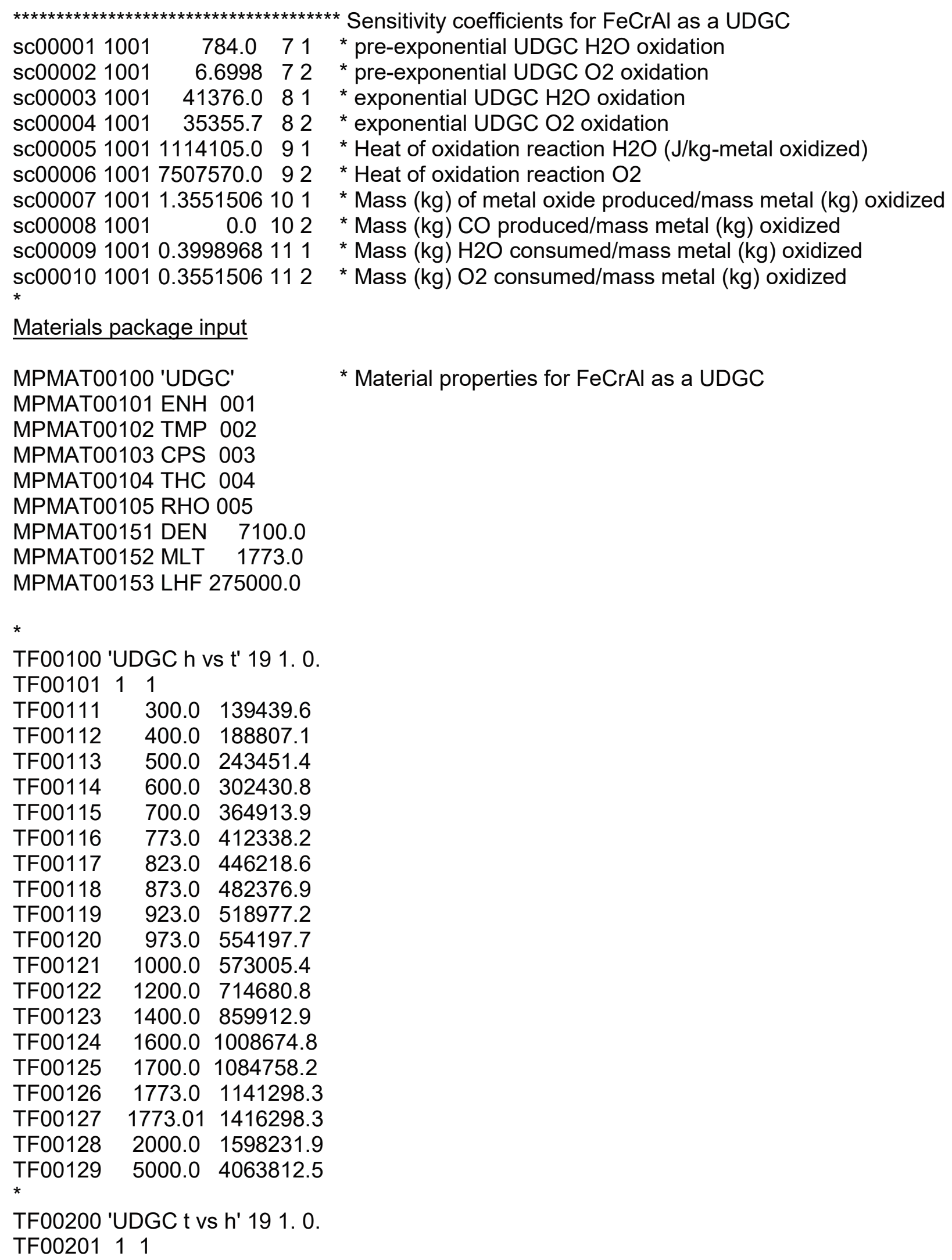

* Material properties for FeCrAl as a UDGC 


\begin{tabular}{|c|c|c|}
\hline TF00211 & 139439.6 & 300.0 \\
\hline TF00212 & 188807.1 & 400.0 \\
\hline TF00213 & 243451.4 & 500.0 \\
\hline TF00214 & 302430.8 & 600.0 \\
\hline TF00215 & 364913.9 & 700.0 \\
\hline TF00216 & 412338.2 & 773.0 \\
\hline TF00217 & 446218.6 & 823.0 \\
\hline TF00218 & 482376.9 & 873.0 \\
\hline TF00219 & 518977.2 & 923.0 \\
\hline TF00220 & 554197.7 & 973.0 \\
\hline TF00221 & 573005.4 & 1000.0 \\
\hline TF00222 & 714680.8 & 1200.0 \\
\hline TF00223 & 859912.9 & 1400.0 \\
\hline TF00224 & 1008674.8 & 1600.0 \\
\hline TF00225 & 1084758.2 & 1700.0 \\
\hline TF00226 & 1141298.3 & 31773.0 \\
\hline TF00227 & 1416298.3 & 1773.01 \\
\hline TF00228 & 1598231.9 & 2000.0 \\
\hline $\begin{array}{l}\text { TF00229 } \\
*\end{array}$ & 4063812.5 & 5000.0 \\
\hline \\
\hline TF00311 & 300.00 & 464.80 \\
\hline TF00312 & 400.00 & 522.55 \\
\hline TF00313 & 500.00 & 570.33 \\
\hline TF00314 & 600.00 & 609.25 \\
\hline TF00315 & 700.00 & 640.41 \\
\hline TF00316 & 773.00 & 658.89 \\
\hline TF00317 & 823.00 & 696.33 \\
\hline TF00318 & 873.00 & 750.00 \\
\hline TF00319 & 923.00 & 714.01 \\
\hline TF00320 & 973.00 & 694.81 \\
\hline TF00321 & 1000.00 & 698.35 \\
\hline TF00322 & 1200.00 & 718.41 \\
\hline TF00323 & 1400.00 & 733.91 \\
\hline TF00324 & 1600.00 & 753.70 \\
\hline TF00325 & 1700.00 & 767.96 \\
\hline TF00326 & 1773.00 & 781.08 \\
\hline TF00327 & 1773.01 & 781.08 \\
\hline TF00328 & 2000.00 & 821.60 \\
\hline TF00329 & 5000.00 & 821.60 \\
\hline \multicolumn{3}{|c|}{ TF00400 'UDGC k vs t' 15 1. 0.} \\
\hline TF00411 & 300.010 & 0.544 \\
\hline TF00412 & 400.012 & 2.574 \\
\hline TF00413 & 500.014 & 4.369 \\
\hline TF00414 & 600.015 & 5.982 \\
\hline TF00415 & 700.017 & 7.463 \\
\hline TF00416 & $800.01 \varepsilon$ & 8.863 \\
\hline TF00417 & 900.02 & 0.235 \\
\hline TF00418 & 1000.02 & 1.629 \\
\hline TF00419 & 1200.02 & 4.691 \\
\hline
\end{tabular}




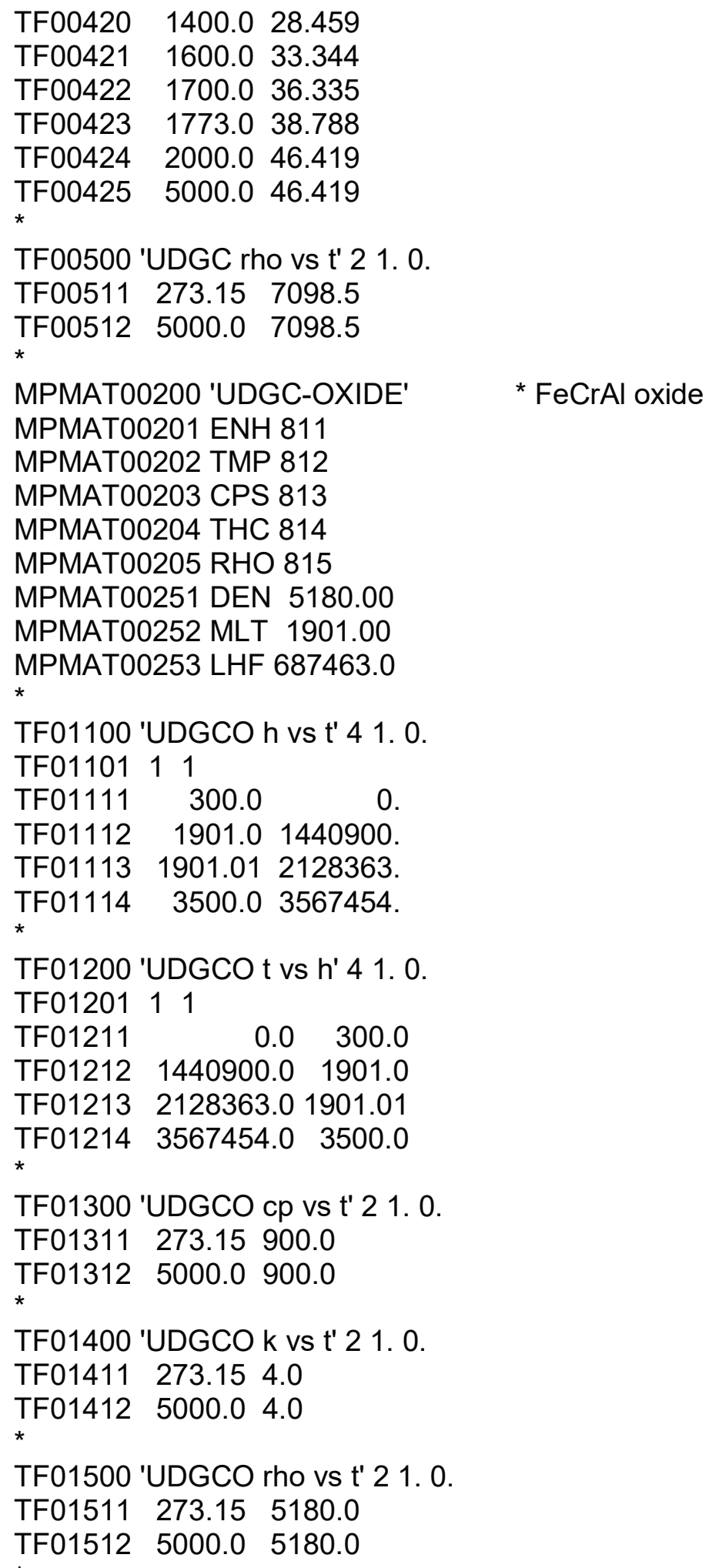

TF01200 'UDGCO t vs h' 4 1. 0.

TF01201 11

$\begin{array}{lll}\text { TF01211 } & 0.0 \quad 300.0\end{array}$

TF01212 $1440900.0 \quad 1901.0$

TF01213 2128363.01901 .01

TF01214 $3567454.0 \quad 3500.0$

*

TF01300 'UDGCO cp vs t' 2 1. 0.

TF01311 273.15 900.0

TF01312 5000.0900 .0

*

TF01400 'UDGCO k vs t' 2 1. 0.

TF01411 273.154 .0

TF01412 $5000.0 \quad 4.0$

*

TF01500 'UDGCO rho vs t' 2 1. 0.

TF01511 $273.15 \quad 5180.0$

TF01512 $5000.0 \quad 5180.0$ 


\section{Application of the Modified MELCOR to the TMI Event}

Previous versions of MELCOR modified to model specific ATF claddings were applied first to a model of the March 1979 Three Mile Island Unit 2 (TMI-2) accident scenario to demonstrate the capability and make some preliminary assessments of the impact of ATF on a real event. We therefore use this same case as a verification problem for the UDGC version of the code, to verify that the same properties supplied via user input reproduce the results obtained with the previous code, in which these were hard-wired.

The TMI-2 accident was caused by a small-break LOCA in a two-loop Babcock \& Wilcox (B\&W) Pressurized Water Reactor (PWR) [12]. Unaware of the small LOCA caused by a stuck-open pilot-operated relief valve (PORV), throughout the first 300 minutes of this event the reactor operators manually overrode the system to operate the Emergency Core Cooling System (ECCS). This action injected water into the reactor pressure vessel (RPV) to cool the reactor core while simultaneously draining the primary cooling system by way of the coolant letdown system in an attempt to prevent the primary system from becoming incompressible (that is, becoming completely filled by water).

Two reactor coolant system (RCS) pumps were operated during the first 100 minutes of this event, providing adequate core cooling; however, increasing pump vibration caused by two-phase water entering these pumps forced the operators to stop RCS pump operation. At $\sim 140$ minutes, the operators became aware of the LOCA and terminated this loss of coolant by closing the appropriate electromagnetic relief valve (ERV) block valve. However, as a result of this accident, the core became uncovered and heated up, causing spacer grid loss by melting, cladding ballooning, control rod meltdown, fuel rod oxidation, hydrogen production, cladding melting, melt candling, fuel melting, molten fuel/cladding pool formation, and a portion of this molten pool pouring into the RPV lower head.

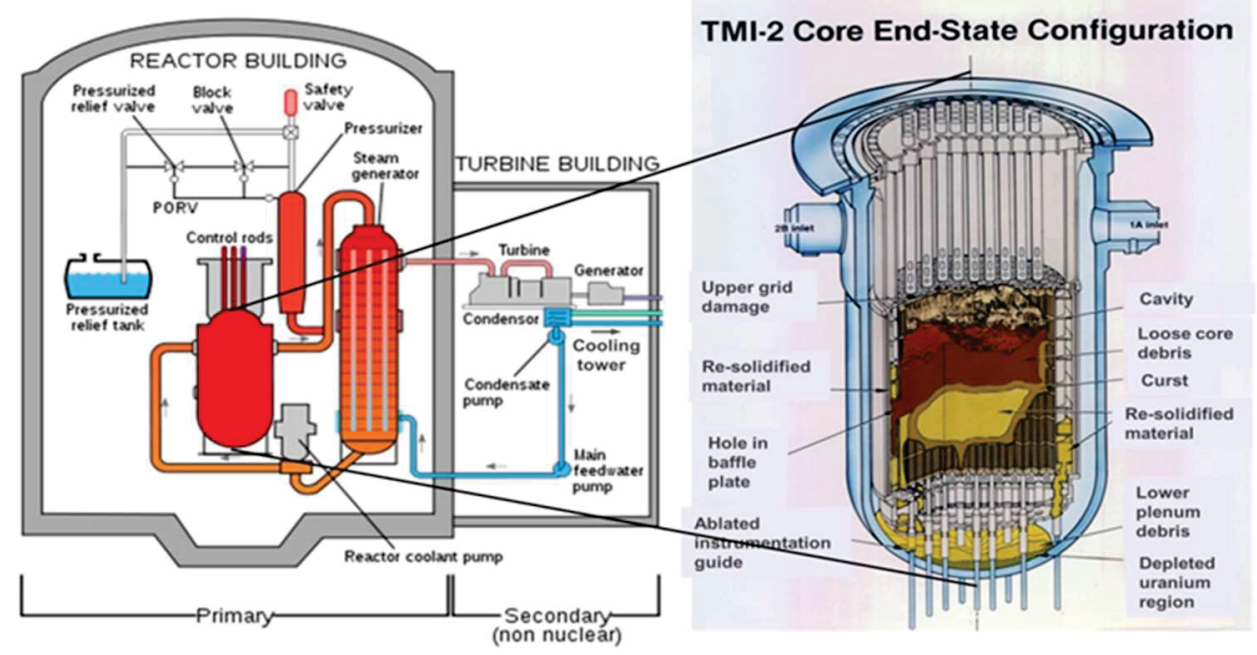

Figure 2. Schematic of TMI-2 reactor and core damage from the LOCA accident. 
The MELCOR model used for this accident was developed by SNL/NM and Innovative Technology Solutions Corporation, Albuquerque, NM [3]. This model was used as received from SNL/NM for the Zircaloy case.

Our verification problem modifies this model such that the $0.67 \mathrm{~mm}$ thick Zircaloy cladding is replaced by a duplex cladding of $0.47 \mathrm{~mm}$ thick Zircaloy covered by an additional $0.2 \mathrm{~mm} \mathrm{FeCrAl}$ clad coating. This model was tested with three different modifications of MELCOR: 1) The original FeCrAl-specific version, with hard-wired properties (this case was described in [4]), 2) The new UDGC version of the code, with the same properties for FeCrAl specified via user input, and 3) The UDGC version of the code with the additional core convection modification described above (denoted "ccnv" in the figures).

Figures 3-4 compare the peak clad temperature and total hydrogen generation for the case with unmodified Zircaloy cladding to our current best estimate for the FeCrAl-coated Zircaloy using the UDGC code with core convection modification. The Zircaloy cladding melts and fails at $\sim 150$ minutes into the accident. Because the oxidation rate for $\mathrm{FeCrAl}$ is much lower than $\mathrm{Zr}$, its predicted cladding temperatures are primarily a result of the fuel's decay heating. The underlying FeCrAl metal does melt at $\sim 150$ minutes, but the temperature peaks at $1796 \mathrm{~K}$ following isolation of the ERV, after which the temperature decreases. This is just below the assumed oxide melt temperature of $1901 \mathrm{~K}$, and therefore the core configuration is predicted to survive intact, provided that this oxide layer can "hold" the fuel and molten FeCrAl in place at these high temperatures and during the subsequent rod quench, though with little margin. As noted in similar prior analyses [4], this conclusion is strongly dependent on the assumed values of the heat of reaction and oxide melt temperature for FeCrAl, which are presently rather uncertain. These properties of $\mathrm{FeCrAl}$ and $\mathrm{FeCrAl}$ oxide need to be determined to make a firm conclusion regarding FeCrAl's full safety benefit as a cladding or coating material during the TMI-2 event. As in previous analyses, the predicted hydrogen generation for FeCrAl-coated Zircaloy is much lower than that for Zircaloy, producing only $10 \mathrm{~kg}$ of hydrogen vs. over $450 \mathrm{~kg}$ for Zircaloy.

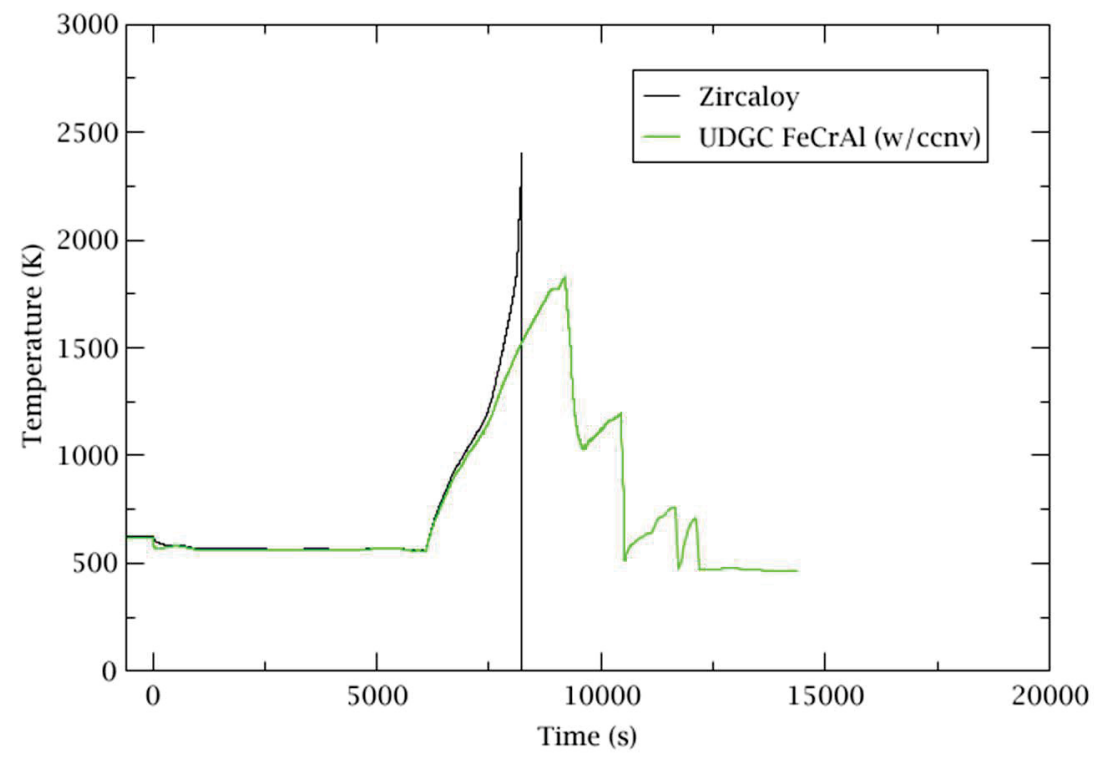

Figure 3. Comparison of MELCOR maximum cladding temperature for Zircaloy and FeCrAl-coated Zircaloy during a TMI-2 accident. 
INL/EXT-17-43162

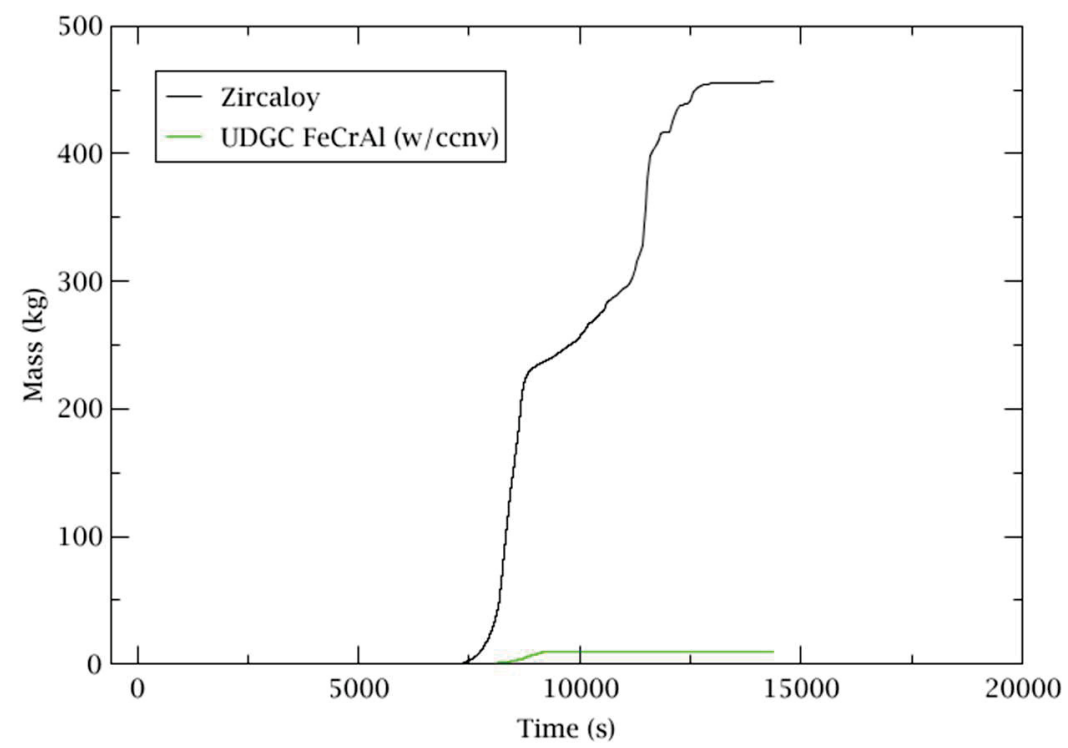

Figure 4. Comparison of hydrogen generation from Zircaloy and FeCrAl-coated Zircaloy cladding during a TMI-2 accident.

Figures 5-6 show the results for peak clad temperature and total hydrogen generation using the same duplex (FeCrAl-coated Zircaloy) cladding described above, run with the three variations of MELCOR also listed above. As expected for the verification problem, there are no significant differences between the hard-wired FeCrAl and UDGC FeCrAl models in either the peak clad temperature and total hydrogen generation, which can be seen in the figures.

The change in the core convection model results in lower heat transfer coefficients in the core, and less heat transfer and higher temperatures overall as a result. The change does not appear dramatic in the peak clad temperature; the FeCrAl metal still melts, and now the oxide reaches $1828 \mathrm{~K}$ (compared to $1796 \mathrm{~K}$ without the change), still tenuously below the assumed oxide melt and clad failure temperature of $1901 \mathrm{~K}$. The difference is evident in the greater amount of hydrogen generated, which is just over $10 \mathrm{~kg}$ as opposed to just over $9 \mathrm{~kg}$ without the correction. 
INL/EXT-17-43162

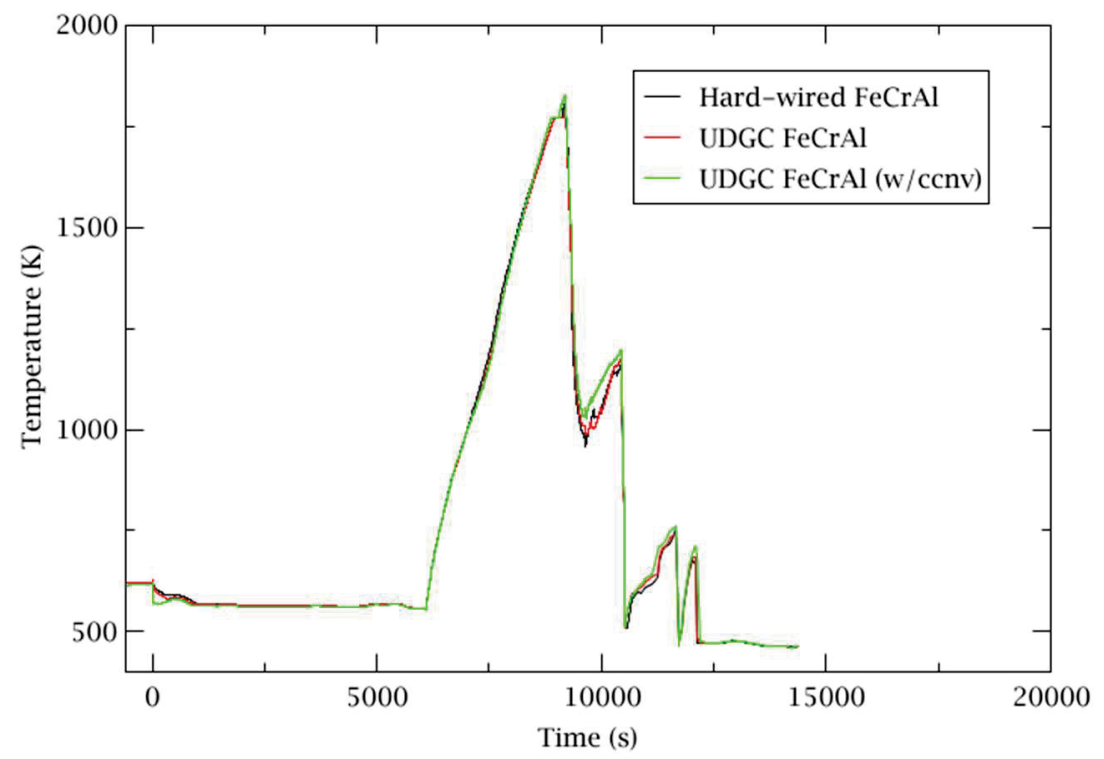

Figure 5. Comparison of MELCOR predicted peak-cladding temperature during a TMI-2 accident.

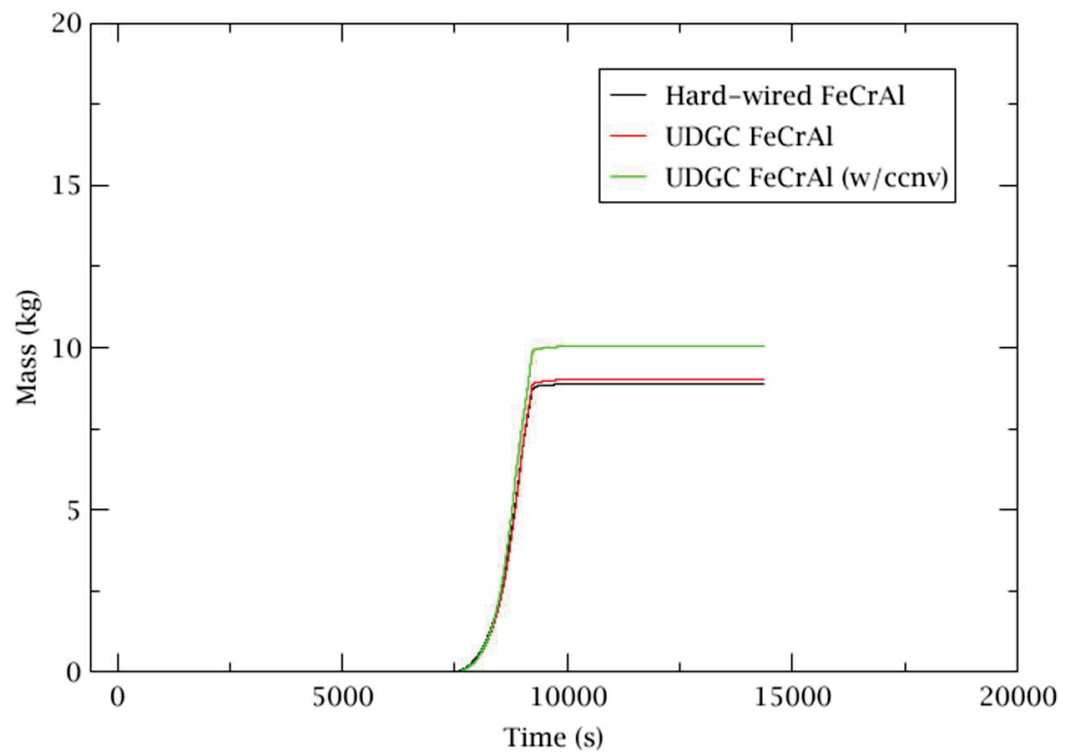

Figure 6. Comparison of MELCOR predicted hydrogen generation produced during a TMI-2 accident. 


\section{Summary, Applications, and Future Work}

This work has resulted in a numerical capability for understanding some of the potential safety advantages of alternate metal cladding or clad coatings over Zircaloy for the cladding of fuel rods during LWR severe accident conditions. Previous versions of the MELCOR code have been supplanted by the newly developed one described here, which allows the user to define any arbitrary clad or clad coating (UDGC) properties in MELCOR's core oxidation and material data package property routines, so long as the material in question undergoes parabolic oxidation. MELCOR evaluates the thermal properties of the composite cladding material by mass weighting material enthalpy and volume weighting material thermal conductivity. The surface oxidation routines assume that the UDGC precedes Zircaloy in oxidation order (i.e., they are applied as a wrap or coating on the external surface of the Zircaloy) if the cladding is duplex. The new UDGC version of MELCOR was verified against previous $\mathrm{FeCrAl}$-specific versions, which were in turn benchmarked against experimental data.

The preliminary result of the TMI verification problem, unchanged from prior analyses, is that FeCrAl does potentially avoid clad melt in this accident scenario, though predictions show that $\mathrm{FeCrAl}$ reaches peak temperatures that are near the adopted failure criterion for a $\mathrm{FeCrAl}$ coating or cladding during this event. If the oxide layer that forms on $\mathrm{FeCrAl}$ is, in fact, alumina, this margin may be greater. Once the aluminum present in the alloy is completely consumed, oxidation of other allow constituents may commence, e.g. iron, which would oxidize at a much higher rate [13]. Modeling this process would require a modification of the code to accept (at least) different Arrhenius parameters depending on the temperature range, a change that will be investigated in the future. To fully realize the safety potential of $\mathrm{FeCrAl}$ as a replacement for Zircaloy cladding, thermal and physical properties of $\mathrm{FeCrAl}$ oxide need to be experimentally determined at high temperatures. In addition, the mechanical behavior at very high temperatures and during rapid thermal quenching of both materials needs to be investigated.

In addition to the TMI test case described here, the FeCrAl-specific version of MELCOR has recently been used by the University of Wisconsin to assess the relative performance of FeCrAl and Zircaloy in a short term station blackout using a model of the Surry PWR [14]. Of particular interest are any synergistic effects of the ATF cladding combined with the possibility of extended auxiliary feedwater (AFW) operation. That study does find such a synergy; using the onset of hydrogen generation as a metric, it was found that the "coping time" between AFW failure and the onset of rapid hydrogen generation was roughly doubled when FeCrAl cladding replaced Zircaloy, see Fig. 7. 
INL/EXT-17-43162

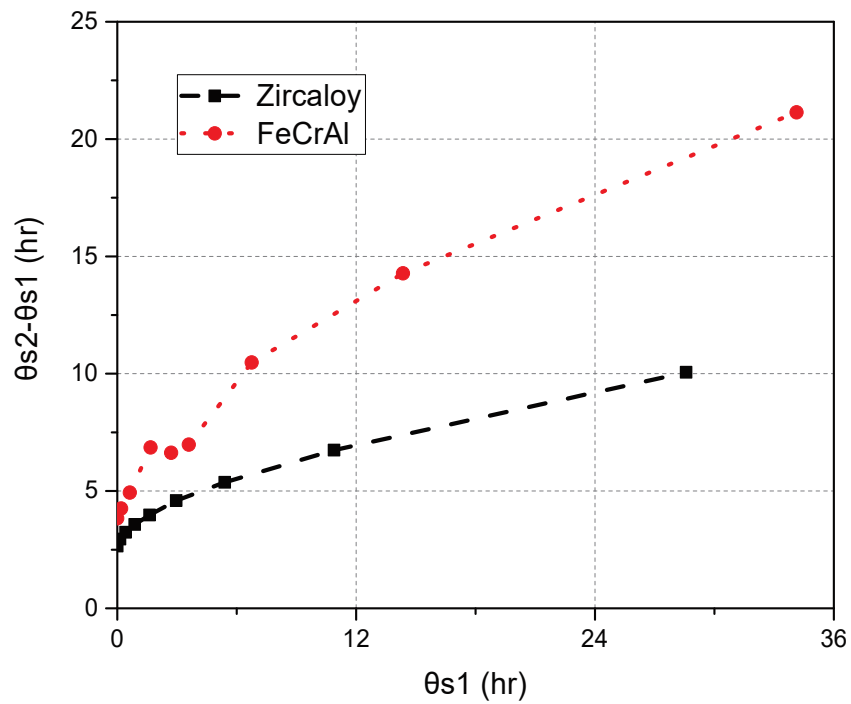

Figure 7. Comparison of the Time Delay between AFW failure and Hydrogen Generation (y axis) versus time (x axis) for Zircaloy Clad and ATF FeCrAl Clad Material (from [14]).

This analysis is currently being modified to include level control in the steam generator. Presently the existing AFW injection and level control systems, as well as alternate models for these developed by $\mathrm{UW}$, encounter code execution issues at some point during the transient. These will continue to be investigated and resolved in the following year. 


\section{References}

1. R. O. Gauntt et al., "MELCOR Computer Code Reference Manuals," NUREG/CR-6119, Vol. 2, Version 1.8.6, September (2005).

2. B. J. Merrill, "MELCOR SiC Modifications for Severe Accident Analysis Applications," Idaho National Laboratory Report, INL/LTD-12-27961, December (2012).

3. R. O. Gauntt, K. Ross, and K. Wagner, "MELCOR 1.8.5 Simulation of TMI-2 Phase 2 With an Enhanced 2-Dimensional In-Vessel Natural Circulation Model," 10th International Conference on Nuclear Engineering, Arlington, Virginia, USA, April 14-18, Vol. 3, pp. 487-494, American Society of Mechanical Engineers (2002).

4. B. J. Merrill, S. M. Bragg-Sitton, and P. W. Humrickhouse, "Status Report on Advanced Cladding Modeling Work to Assess Cladding Performance Under Accident Conditions," INL/EXT-13-30206 rev. 2, August 2015.

5. K. R. Robb, "Analysis of the FeCrAl Accident Tolerant Fuel Concept Benefits During BWR Station Blackout Accidents," Proc. of NURETH-16, Chicago, IL, USA, August 30-September 4, 2015.

6. W.F. Brown and S.J. Setlak (eds), Aerospace Structural Metals Handbook, 37th Edition, 2001.

7. http://www.kanthal.com/en/products/material-datasheets/tube/kanthal-apmt/

8. http://www.matweb.com/search/DataSheet.aspx?MatGUID=8579651022af4ab9bff27618e7da94da

9. K. A. Terrani, S. J. Zinkle, and L. L. Snead, "Advanced oxidation-resistant iron-based alloys for LWR fuel cladding," Journal of Nuclear Materials, 448 (2014) 420-435.

10. B. A. Pint, et al., "High temperature oxidation of fuel cladding candidate materials in steam-hydrogen environments," Journal of Nuclear Materials, 440 (2013) 420-427.

11. C. Badini , F. Laurell, "Oxidation of FeCrAl alloy: influence of temperature and atmosphere on scale growth rate and mechanism," Surface and Coatings Technology, 135, (2001) 291-298.

12. R. E. Henry, TMI-2: An Event in Accident Management for Light-Water-Moderated Reactors, American Nuclear Society, La Grange Park, Illinois (2001).

13. K. R. Robb, J. W. McMurray, and K. A. Terrani, "Severe Accident Analysis of BWR Core Fueled with $\mathrm{UO}_{2} / \mathrm{FeCrAl}$ with Updated Materials and Melt Properties from Experiments," ORNL/TM2016/237, June 2016.

14. J. Wang, T. C. Haskin, and M. L. Corradini, "Severe Accident Progression and the Effects of Accident Tolerant Cladding,” NURETH-17, Xi’an, China, September 3-8, 2017. 